\title{
Preliminary Results of Paclitaxel, Cisplatin and Concurrent High-Dose Radiation Therapy for Locally Advanced Non-Small-Cell Lung Cancer
}

Sang-wook Lee, M.D. ${ }^{1}$, Eun Kyung Choi, M.D. ${ }^{1}$, Suk Joong Oh, M.D. ${ }^{2}$, Cheolwon Suh, M.D. ${ }^{2}$, Sang-We Kim, M.D. ${ }^{2}$, Jung Shin Lee, M.D. ${ }^{2}$, Dong Soon Kim, M.D. ${ }^{2}$, Won-Dong Kim, M.D. ${ }^{2}$, Woo Seong Kim, M.D. ${ }^{2}$, Sang Do Lee, M.D. ${ }^{2}$, Jong Hoon Kim, M.D. ${ }^{1}$, Seung Do Ahn, M.D. ${ }^{1}$, Kyoung Ju Kim, M.D. ${ }^{1}$ and Young Ju Noh, M.D. ${ }^{1}$

Departments of ${ }^{1}$ Radiation Oncology, ${ }^{2}$ Internal Medicine, Asan Medical Center, College of Medicine, University of Ulsan, Seoul, Korea

Purpose: To investigate the feasibility, toxicity and response rate, of concurrent chemoradiation therapy with paclitaxel/cisplatin in stage III locally advanced non-small cell lung cancer (NSCLC).

Materials and Methods: Between May 1999 and December 2000, 80 patients with stage III NSCLC were enrolled in a prospective protocol. Radiotherapy was given to a total dose of $70.2 \mathrm{~Gy}$ (daily fraction of 1.8 Gy for 5 days), over an 8 week period, on the gross tumor volume, combined with chemotherapy. The con. current chemotherapy consisted of paclitaxel $\left(40 \mathrm{mg} / \mathrm{m}^{2}\right)$ and $20 \mathrm{mg} / \mathrm{m}^{2}$ cisplatin per week for 8 consecutive weeks. All patients received 3-D conformal radio. therapy using $C T$-simulated planning. Acute toxicities were evaluated by the RTOG scale. The median followup period was 16 months, ranging from 3 to 29 months.

Results: Of the 80 patients, 71 received treatment per protocol, with minor variation of protocol delivery. The median age of the patients was 60 years. Karnofsky Performance status were 100 and 90 in 62 patients, and 80 and 70 in 9 , respectively. Weight loss of less than $5 \%$ for 6 months was observed in 22

\section{서 론}

국내에서 폐암의 발생률은 지속적으로 증가하고 있으며

Correspondence: Eun Kyung Choi, Department of Radiation Oncology, Asan Medical Center, University of Ulsan, 388-1 Pungnapdong, Songpa-gu, Seoul 138-736, Korea. (Tel) +82-2-30104432, (Fax) +82-2-486-7258, (E-mail) ekchoi @amc.seoul.kr Received April 15, 2002, Accepted September 26, 2002 Acknowledgment: Oral presented at the 19th KOSTRO, Seoul, Korea, October 12th and 13th, 2001. patients. The response to treatment was evaluated from the radiological findings. Complete and partial responses were observed in 8 and 51 patients, respectively. Ultimately, $82 \%$ of patients (included complete responses: 8 cases) obtained more than a partial response. Although, radiation induced esophagitis was the most common treatment related toxicity, occurring in 44 patients $(69 \%)$, severe radiation esophagitis like, grade 3 , was observed in only 3 patients, and the most acute toxicities had completely recovered 1 month following treatment. The overall 2-year actuarial and progression free survivals were 56 and $45 \%$, respectively.

Conclusion: This combined modality has activity with manageable toxicity and 23 months in mean survival time in patients with stage III NSCLC. A longer follow up will be required to realise the expected higher survival of these results. (Cancer Research and Treatment 2002;34:345-351)

Key Words: Non-small cell lung cancer, Concurrent chemoradiation, Conformal radiotherapy

(1), 현재 암으로 인한 사망률 1 위를 차지하고 있다. 진단당 시 수술적 절제가 불가능한 비소세포폐암의 치료성적은 매 우 불량하여 5 년 생존율은 $10 \%$ 이내이다(2 5). 진행된 비 소세포폐암의 이런 저조한 치료율의 향상을 위한 다양한 노력들이 진행되었지만 아직까지 만족스러운 성적은 얻지 못하고 있다. 다만 Dillman등이 cisplatin을 이용한 유도항암 화학요법과 방사선치료 $(60 \mathrm{~Gy})$ 를 이용한 무작위 3상 임상 연구에서 통계적으로 유의한 생존율 향상을 보고한(6) 후 비소세포폐암에서 기존의 방사선치료에 항암화학요법을 추가하는 연구가 활발히 진행되고 있다. 방사선치료 전후 


\section{Cancer Research and Treatment 2002;34(5)}

에 항암화학요법을 추가하거나 동시 항암화학방사선요법 을 시행하는 다양한 치료방법이 시도되고 있다. 아직까지 다양한 치료방법들 중에서 최선의 치료방법은 증명되지 못 하였지만 이론적으로 동시 항암화학방사선 요법은 방사선 치료의 효과를 항암제가 증진시킬 수 있고 조기에 방사선 치료가 시작되므로 항암제에 내성이 있는 세포수가 적을 때 사멸시킬 수 있는 등 많은 장점을 가지고 있다. 다양한 항암화학요법제 중에서 paclitaxel과 cisplatin은 비소세포폐 암에 대한 반응률이 높고(7), 비교적 적은 용량에서도 방사 선치료의 감수성을 증가시키며(8) 치료독성도 낮은 것으로 알려져 있다(9). 본원에서는 1993년 후부터 폐암의 치료에 서 동시항암화학방사선 요법을 시도하여 왔으며 1999년도 중반까지 MVP (Mitomycin C $6 \mathrm{mg} / \mathrm{m} 2 \mathrm{~d} 2$ \& d29, Vinblastine $6 \mathrm{mg} / \mathrm{m} 2 \mathrm{~d} 2 \& \mathrm{~d} 29$, Cisplatin $60 \mathrm{mg} / \mathrm{m} 2 \mathrm{~d} 1$ \& d28) 요법(10)을 종료하고 paclitaxel과 cisplatin (TP) 요법을 이용한 동시항암 화학방사선(총 $70.2 \mathrm{~Gy})$ 을 표준으로 결정하여 제 2 상 임상연 구를 시행하고 있다. 이에 본 저자들은 고선량의 방사선치 료와 동시항암화학요법의 급성치료독성과 순응도를 평가 하고 조기 치료반응 및 성적을 보고하고자 본 연구를 진행 하였다.

\section{대상 및 방법}

\section{1) 대상환자의 선정}

1999년 5월부터 2000년 12월까지 서울아산병원에서 비소 세포폐암으로 진단받고 근치적 목적의 항암화학방사선 동 시요법 치료를 시행받은 환자들에 대한 분석을 시행하였 다. 연구대상에 포함되기 위한 조건은 병리조직학적으로 진단받고, 과거력에 폐암으로 치료받은 경험이 없는 환자 들 중에서 수술적 절제가 불가능하면서 원격장기로의 전이 가 없는 경우로 하였다. 이학적 검사에서 쇄골상 림프절 종 괴가 발견되어 조직검사에서 확진된 경우는 연구대상에 포 함하였다. 대상 환자의 치료 순응도를 예측하기 위한 조건 으로 신체 활동도가 Karnofsky 스케일로 70 이상인 환자들 을 연구대상에 포함하였다. 병기결정을 위한 흉부 엑스선 촬영, 흉부 전산화단층촬영에서 수술적 절제가 불가능한 IIIB 병기이거나, 국소적으로 진행되어 종격동 내 림프절 종괴가 진행되어 있어 병기 결정상 IIIA라 하더라도 수술이 불가능한 경우 연구대상에 포함하였고, 골전이 가능성을 배제하기 위하여 방사선동위원소 전신 골 촬영을 시행하였 고, 간 전이를 배제하기 위하여 흥부 전산화단층촬영 시 전 간과 부신 피질을 촬영 범위에 포함하여 원격전이 여부를 판정하였다. 문진과 이학적 검진에서 특이소견이 없는 경
우 뇌전이 여부를 판정하기 위한 방사선검사는 시행하지 않았다. 그와 일반혈액검사, 간기능 검사, 폐기능검사를 통하여 항암치료나 방사선치료의 가능 여부에 대한 판단 을 하였다.

\section{2) 치료방법 및 평가}

방사선치료는 일일 1 회 $1.8 \mathrm{~Gy}$ 분할량으로 주 5 회 조사하 였으며, 방사선치료 초기에는 전후 2 문 조사방법으로 41.4 $\mathrm{Gy}$ 까지 조사한 후 전산화단층촬영을 이용한 모의치료 계 획을 시행하여 총 $70.2 \mathrm{~Gy}$ 까지 조사하였는데, 이 때 척수의 견딤 선량을 $45 \mathrm{~Gy}$ 로 하고 잔여 정상 폐를 최대한 보호하기 위한 3 차원 치료계획을 시행하였다. 이 때 만약 정상 폐에 과다한 방사선량이 조사될 가능성이 있는 환자에서는 비동 일면상에서 조사면 수를 증가시켜 3 차원 입체조형치료의 최적화를 시행하였다. 총방사선치료 기간은 평균 8 주가 소 요되었다. 방사선치료를 하는 동안 매주 paclitaxel $(40 \mathrm{mg} /$ $\left.\mathrm{m}^{2}\right)$ 과 cisplatin $\left(20 \mathrm{mg} / \mathrm{m}^{2}\right)$ 을 정주하여 8 회 동시 투여하였다.

치료 독성을 평가하기 위하여 RTOG 기준에 따른 급성독 성을 평가하였다. 치료 중 매주 1 회 외래를 통한 검진을 시 행하여 환자의 상태를 파악하였으며, 백혈구가 $2,000 / \mathrm{mm}^{3}$ 이하이거나 혈소판 수치가 $50,000 / \mathrm{mm}^{3}$ 이하인 경우 치료 를 중단하고 주 2 회 일반혈액검사를 확인하였다. 만약 백 혈구 수치가 $2,000 / \mathrm{mm}^{3}$ 이하인 경우에는 GM-CSF를 투여 하였다.

Table 1. Patient characteristics

\begin{tabular}{llc}
\hline \multicolumn{1}{c}{ Variables } & & $\begin{array}{c}\text { No. of } \\
\text { patients }(\%)\end{array}$ \\
\hline Age (years) & Range & $35 \sim 74$ \\
& Median & 60 \\
Gender & Male & $64(91.1)$ \\
& Female & $7(9.9)$ \\
Weight loss & $\leq 5 \%$ & $48(67.6)$ \\
& $>5 \%$ & $23(32.4)$ \\
Performance status & $100 \sim 90$ & $62(87.3)$ \\
& $80 \sim 70$ & $9(12.7)$ \\
Stage & IIIA & $8(11.3)$ \\
& IIIB & $63(88.7)$ \\
Pathology & Squamous cell carcinoma & $46(64.8)$ \\
& Adenocarcinoma & $16(22.5)$ \\
& Type unspecified & $9(12.7)$ \\
\hline
\end{tabular}




\section{3) 추적조사 및 통계처리방법}

종양의 반응은 방사선치료 종료 후 1 개월과 3 개월에 시 행한 흥부전산화단층촬영을 통하여 평가하였다. 추적조사 기간은 3 개월에서 29 개월이었다(중앙값: 16 개월). 전체 생 존기간과 질병 진행기간을 산출하기 위한 방법으로 KaplanMeier 방법을 이용하였다.

\section{결 과}

\section{1) 대상환자의 특성}

연구대상에 포함된 환자는 80 명이었고, 이 중 계획된 치료 를 종료하지 못한 경우는 9예로 치료의 순응도는 $89.2 \%$ 였 으며, 71 명에 대한 분석을 시행하였다. 대상환자의 남녀 비 는 $64: 7$ 이었고, 연령은 35세부터 74세(중앙연령: 60세)였 다. 신체 활동도는 90 이상이 62명, 80 70이 9명이었고, 진 단당시 체중 감소가 $5 \%$ 이상인 경우는 23 명이었다. 병리조 직학적으로 편평상피세포암이 46예였고, 선암이 16예였고, 그 외 병리조직학적 분류가 불가능한 경우는 9예였다(Table 1). 전체 대상 환자의 병기분포를 살펴보면 $\mathrm{T} 4$ 인 경우가 50 예(70\%)였고, N3인 경우가 30예(42\%)로 쇄골상림프절 종괴 가 있었던 경우는 14 예였다(Table 2).

Table 2. TNM stage of patients

\begin{tabular}{cccccc}
\hline $\mathrm{T}$ & $\mathrm{T} 1$ & $\mathrm{~T} 2$ & $\mathrm{~T} 3$ & $\mathrm{~T} 4$ & Total \\
\hline $\mathrm{N} 0$ & - & - & 2 & 4 & 6 \\
$\mathrm{~N} 1$ & - & - & 0 & 6 & 6 \\
$\mathrm{~N} 2$ & 0 & 2 & 5 & 20 & 27 \\
$\mathrm{~N} 3$ & 2 & 7 & 3 & 20 & $30 *$ \\
\hline Total & 2 & 10 & 9 & 50 & 71 \\
\hline
\end{tabular}

*14 patients had supraclavicular lymph node metastasis

Table 3. Response rate of concurrent chemoradiation therapy

\begin{tabular}{lc}
\hline Type of response & No. of patients $(\%)$ \\
\hline Complete response & $8(11)$ \\
Partial response & $51(72)$ \\
No response & $10(14)$ \\
Progressive disease & $2(3)$ \\
\hline Total & $71(100)$ \\
\hline
\end{tabular}

\section{2) 치료성적}

방사선치료 종료 후 1 개월과 3 개월에 시행한 흥부전산화 단층촬영 결과 완전관해를 보인 경우는 8 예였고, 부분관 해 이상을 보인 경우는 59예(완전관해 8 예 포함)로 $83 \%$ 였 다(Table 3). 2년 전체 생존율은 $56 \%$ 였고(Fig. 1), 무질병진 행 생존율은 $45 \%$ (중앙생존기간은 23개월, $95 \%$ CI: 14 32 개월)이었다. 방사선치료 종료 후 추적조사 중 국소재발은 10 예로 $14 \%$ 였고, 원격장기의 재발은 16 예(23\%)에서 관찰 되었다. 진단 당시 종양이 있었던 원발병소에서 재발된 경 우는 9예(13\%)였다. 반대측 폐에서 재발하거나 단측 또는 양측 폐에 혈행성 전이를 보인 경우는 4 예였고, 반대측 쇄 골상림프절에서 재발한 경우도 1 예 있었다. 그 외 뇌전이가 7예, 골전이가 3예, 간전이가 3예 발생하였다(Table 4). 치료 와 연관되어 치료독성으로 사망한 경우는 2 예였고 치료가 1 주 이상 중단된 경우는 3 예였다. 방사선치료 중 발생한 급

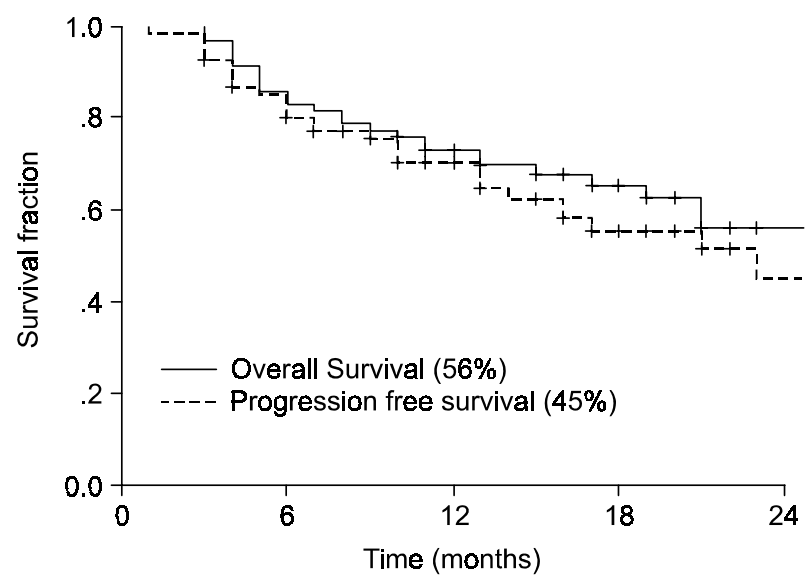

Fig. 1. Two-year overall survival and progression free survival curves.

Table 4. Patterns of failure

\begin{tabular}{cc}
\hline Type of recurrence & No. of patients $(\%)$ \\
\hline Locoregional & $10 / 71(14)$ \\
Primary site & 9 \\
Supraclavicular nodes & 1 \\
Distant & $16 / 71(23)$ \\
Brain & 7 \\
Lung & 4 \\
Bone & 3 \\
Liver & 3 \\
Other* & 3 \\
\hline
\end{tabular}

*skin, pericardial effusion, pelvic cavity 
Table 5. Esophageal complications by RTOG scale

\begin{tabular}{llc}
\hline Grade & \multicolumn{1}{c}{ Criteria } & Incidence \\
\hline 0 & No change over baseline & $18(25 \%)$ \\
1 & Mild dysphagia or odynophagia/ may require topical anesthetic or non-narcotic analgesics/may & $32(45 \%)$ \\
& require soft diet & $17(24 \%)$ \\
2 & Moderate symptom/ may require narcotic analgesics/ may require puree or liquid diet & $4(6 \%)$ \\
3 & Severe symptom with dehydration or weight loss $(>15 \%$ from pre-treatment baseline) requiring & \\
$\quad$ Naso-Gastric feeding tube, I.V. fluids or hyperalimentation & $0(0 \%)$ \\
4 & Complete obstruction, ulceration, perforation, fistula &
\end{tabular}

Table 6. Hematologic complications (RTOG scale)

\begin{tabular}{|c|c|c|c|c|c|}
\hline & Grade 0 & Grade 1 & Grade 2 & Grade 3 & Grade 4 \\
\hline \multicolumn{6}{|c|}{ WBC $\left(\times 1000 / \mathrm{mm}^{3}\right)$} \\
\hline Criteria & $\geq 4.0$ & $3.0 \sim<4.0$ & $2.0 \sim<3.0$ & $1.0 \sim<2.0$ & $<1.0$ \\
\hline Incidence & $58(82 \%)$ & $10(14 \%)$ & $3(4 \%)$ & 0 & 0 \\
\hline \multicolumn{6}{|c|}{ Platelets $\left(\times 1000 / \mathrm{mm}^{3}\right)$} \\
\hline Criteria & $<1.0$ & $75 \sim<100$ & $50 \sim \leq 75$ & $25 \sim<50$ & $\begin{array}{c}<25 \text { or spontaneous } \\
\text { bleeding }\end{array}$ \\
\hline Incidence & $69(97 \%)$ & $2(3 \%)$ & 0 & 0 & 0 \\
\hline \multicolumn{6}{|c|}{ Hemoglobin $(\mathrm{g} / \mathrm{dL})$} \\
\hline Criteria & $>11$ & $11 \sim 9.5$ & $<9.5 \sim 7.5$ & $<7.5 \sim 5.0$ & - \\
\hline Incidence & $50(70 \%)$ & $15(21 \%)$ & $6(9 \%)$ & 0 & \\
\hline
\end{tabular}

Table 7. Radiation pneumonitis by RTOG scale

\begin{tabular}{llc}
\hline Grade & \multicolumn{1}{c}{ Criteria } & Incidence \\
\hline 0 & None & $30(42 \%)$ \\
1 & Asymptomatic or mild symptoms (dry cough), slight radiographic appearances & $28(39 \%)$ \\
2 & Moderate symptomatic fibrosis or pneumonitis (severe cough), low grade fever, patchy & $10(14 \%)$ \\
& $\quad$ radiographic appearances & $3(4 \%)$ \\
4 & Severe symptomatic fibrosis or pneumonitis dense radiographic changes & $0(0 \%)$ \\
\hline
\end{tabular}

성독성은 RTOG 기준에 따라 분류하였는데, 방사선에 의한 식도염이 가장 흔히 발견되었으며 grade 1 이상인 경우는 44 예로 $68.8 \%$ 였지만, grade 3 는 3 예에 불가하였고 치료가 중단 된 경우는 없었다(Table 5). 항암제에 의한 골수기능 저하는 심각하지 않아 계획된 치료를 수행하는 데 제한 요 인으로 생각되지 않았다(Table 6). 대부분의 급성 합병증은 치료종료 후 별다른 치료 없이 회복되었다. 방사선치료에 의한 방사선폐렴은 $58 \%$ 에서 발생하였는데, 전체 발생환자
의 대부분인 $53 \%$ 가 grade 2 이하의 비교적 심각하지 않은 합병증만 발생하였다(Table 7).

\section{고 찰}

폐암은 발생빈도가 높을 뿐더러 사망률도 매우 높은 난 치병이다. 비소세포 폐암은 진단 당시 수술적 절제가 불가 능한 경우가 $80 \%$ 정도이고, 수술적 치료를 받지 못한 환자 
들은 어떤 치료를 시행 받아도 결국 대부분 사망하게 된다. 따라서 수술적 절제가 불가능한 국소적으로 진행된 비소세 포폐암의 생존율을 조금이라도 높일 수 있는 치료방법이 개발된다면 실제로 많은 수의 환자 생명을 구할 수 있을 것이다. 이러한 이유로 전 세계적으로 많은 치료기관에서 다양한 새로운 치료방법을 시도하였으나, 기존의 치료와 비교하여 통계적으로 유의한 차이를 보이는 제 3 상 임상연 구 결과는 불과 몇 개에 불과하다 $(6,11)$. 이런 연구 결과들 중에서 Dillman 등이 cisplatin을 이용한 유도화학요법 3회 후 방사선치료 $60 \mathrm{~Gy}$ 를 조사한 경우 약 4개월 정도의 중앙 생존 값의 연장 가능성을 보고하였다(6). 또한 RTOG study 에서도 위의 결과를 확인할 수 있었다(11). 이후 이 결과는 장기간 추적조사결과에서 확인되었다 $(4,13)$. 하지만 상기 치료결과는 만족스럽지 않았고, 더 높은 치료성적을 얻을 수 있는 치료방법이 절실히 요구되고 있다. 이런 연구 결과 의 치료실패양상을 분석하여 보면 대부분 완전반응을 보인 경우는 $4 \%$ 에서 $37 \%$ 로 다양할 뿐더러 평가하기도 용이하지 않다 $(6,14)$. 본 연구에서는 완전반응률을 8 예 $(11 \%)$ 로 보고 하였는데 완전반응을 판단하는 것이 용이하지는 않다. 방 사선조사 후 병리조직학적으로 잔존 암을 진단하는 것이 용이하지 않을 뿐더러, 우선 모든 환자에서 실제 임상에서 조직 검사를 하는 것이 환자의 동의나 부작용 등을 고려하 면 거의 불가능하다고 생각된다. 방사선학적인 판정 시 흥 부전산화단층 촬영을 하는 것은 비교적 용이하나 진단의 정확도 면에서 많은 문제점들을 가지고 있다. 방사선종료 후 종양의 사멸은 1 개월에서 2 개월 후에도 일어나고 동시 에 방사선에 의한 폐렴과 섬유화가 진행되어 반응정도를 파악하는 것이 매우 어려워 제시된 완전반응률도 실제와는 차이가 있을 것으로 생각된다.

Arriagada등이 무작위 3상 임상연구에서 방사선치료만 하 거나 항암제를 투여한 경우 각각 $17 \%, 15 \%$ 만이 사망 시까 지 국소제어되고 결국 $85 \%$ 는 흥곽 내 국소제어에 실패하고 대부분 사망하게 된다고 보고하여 $(5,15)$ 국소제어에 성공하 는 것이 일차적 치료 목표라 할 수 있다. 방사선치료를 통하 여 국소제어율을 향상시키기 위하여 크게 두 가지 방법을 생각해 볼 수 있다. 첫째는, 합병증 없이 방사선치료선량을 증가시키는 것이고(12,16,17), 둘째는 방사선치료 효과를 증 진시키는 것이라 할 수 있는데 그 방법 중의 하나는 항암화 학요법과 동시방사선치료를 시행하여 방사선치료의 효과 를 증진시키는 것이라 할 수 있다. 본 연구에서 사용된 paclitaxel과 cisplatin은 방사선 효과를 증진시키는 것으로 알려져 있고(8) 유도항암화학요법의 효과가 증명되어 있기 는 하지만 그 결과는 만족스럽지 않아 동시항암화학방사선 방법을 시도하였고 반응률도 $83 \%$ 로 만족스러운 결과를 얻
었다고 생각된다.

방사선량을 증가시키기 위한 RTOG 연구결과에 따르면 총선량 $60 \mathrm{~Gy}$ 이상에서 선량반응관계가 없는 것으로 판명 되어 $60 \mathrm{~Gy}$ 가 표준으로 되어 왔으나(12) 일일 2회 조사하는 과분할조사 방법이 시도되면서 $69.4 \mathrm{~Gy}$ 에서 향상된 치료 결과를 얻을 수 있었다(11,16). 이 방법은 이후 역시 무작위 3상 임상연구에서 확인되었다(11). 본원에서는 통상 사용하 는 1 일 1 회 $1.8 \mathrm{~Gy}$ 를 조사하는 방법으로 $70.2 \mathrm{~Gy}$ 를 조사하 였다. 한편, 과분할 방사선치료의 이론적 배경은 방사선에 의한 정상조직의 합병증을 줄여 총선량을 올릴 수 있다는 점인데, 본 연구에서 과분할방사선 치료방법을 이용하지 않은 이유는 3 차원 입체조형치료를 시도하였기 때문이다. 3 차원 입체조형치료는 주변정상장기의 합병증을 현저히 줄일 수 있는 기술적 방법으로 알려져 있다(18 21). 본원 에서는 1994년 3차원 입체조형치료가 시작되면서 이후 모 든 환자를 전산화모의치료방법을 이용한 3 차원 입체조형 치료를 적용하고 있다. 따라서 통상 항암화학요법과 동시 방사선치료를 하는 경우 방사선치료선량을 줄이는 것이 일 반적이지만 본원에서는 기존의 방법과 상이하게 더 선량을 증가시키는 방법을 시도하였는데, 그 이유는 국소제어율을 향상시키기 위해서이다. 고선량의 방사선치료를 하면서 항 암제를 동시에 투여하는 본 방법이 안전한 방법으로 생각 된 점은 본 연구 결과에서 가장 중요한 결과 중의 하나로 생각된다.

비소세포폐암에서 방사선치료에 부가하여 항암화학요법 이 생존율 향상을 증명한 Dillman의 연구 결과는 4 개월의 중앙생존기간을 연장하였지만, RTOG에서 확인 연구 결과 에 따르면 약 2 개월 정도밖에 연장되지 않는 것으로 판명되 었다(3). 특히 Dillman의 CALGB 연구대상은 비교적 예후가 좋을 것으로 판단되는 환자들을 대상으로 한 단점을 가지 고 있어 수술적 절제 불가능한 모든 비소세포폐암 환자에 서 생존율이 향상될지는 의문이다. 항암제를 추가하는 것 이 생존율 향상에 도움을 준다는 사실을 인정한다 해도 과 연 순차적인 방법과 동시요법의 우월성은 명확히 증명되지 못한 상태이다. Furuse등이 항암제의 순차적 방법과 동시요 법 사이의 차이를 확인하기 위한 무작위 3상 연구결과에 따르면 동시요법이 더 우월한 것으로 보고하였다(22). 동시 항암방사선요법을 시행함에 있어서 방사선치료의 감수성 을 증가시키기 위한 항암화학 동시방사선용법은 일차적으 로 방사선치료 효과를 증진시킬 수 있는 약제를 선택하는 것이 중요하다. 방사선치료의 감수성을 증가시키는 약제로 는 다양한 약제들이 알려져 있는데, 본 연구에서 사용된 paclitaxel과 cisplatin은 모두 방사선치료의 효과를 증진시키 는 대표적인 약제로 알려져 있다(8). 본원에서 사용하는 
paclitaxel의 용량은 Choy 등이 이미 그 치료 효과나 안정성 을 확인한 바 있다(23). 하지만 cisplatin의 경우 구강과 식도 점막의 염증을 일으키는 부작용을 가지고 있고 특히 방사 선치료를 하는 경우 식도에 독성을 나타내어 방사선식도염 을 악화시킬 수 있는 단점이 있는 약제이다. 따라서 방사선 치료를 계획된 일정에 따라 시행하기가 용이하지 않고, 만 약 방사선에 의한 식도염이 발생하는 경우 적극적인 보존 적 치료가 필요하다고 생각되었다. 방사선치료를 $41.4 \mathrm{~Gy}$ 조사 후 전산화단층촬영상에서 가능한 식도를 표적체적에 포함하지 않으려 노력했고 $41.4 \mathrm{~Gy}$ 후부터는 방사선식도염 의 강도나 발생빈도가 감소하였다. 전산화단층촬영을 이용 한 모의치료방법은 표적체적을 정확하게 결정할 수 있어 비교적 많은 체적의 정상 폐조직과 주변 정상조직을 보존 할 수 있는 방법이기 때문에 총선량을 $70.2 \mathrm{~Gy}$ 로 올려도 기 존의 방사선치료와 비교하여 방사선조사에 의한 합병증을 줄일 수 있었다.

본 연구에 포함되기 위한 조건은 방사선치료를 시행 받 을 수 있는 모든 환자들을 대상으로 하였고, 특별히 방사선 치료 자체를 포기하지 않은 대부분의 환자들이 본 연구에 포함되었다. 따라서 다른 연구보다는 대상환자 적응증이 광범위하다고 할 수 있다. 치료에 대한 순응도는 계획된 치 료의 3 분의 2 이상을 치료받은 환자들을 대상으로 파악한 결과 $90 \%$ 였고 치료에 의한 급성 독성으로 방사선치료를 연속으로 1 주 이상 중단하거나 5 일 이상 2 회 치료가 중단 경우는 없었다. 특히 골수기능 저하에 의한 백혈구 수치 저 하로 치료가 중단되는 경우 매우 드물었고 백혈구 수치가 $2,000 / \mathrm{mm}^{3}$ 이하로 떨어진 경우 GM-CSF를 투여 받고 정상 으로 골수 기능이 회복되었다. 하지만 $70 \%$ 이상의 환자에 서 방사선 식도염이 발생하였고, 증상의 강도에 따라 보존 적 치료를 시행하여 방사선치료 종료 후 1 개월에서 2 개월 사이에 모두 회복되었다. 치료와 직접 연관되어 사망한 경 우는 단 2 예로 폐렴으로 인한 호흡곤란으로 사망하였고 1 예에서는 자의로 치료 중단 후 집에서 사망하여 구체적인 원인을 알 수 없었다. 비록 2예에서 사망한 경우가 있었지 만 매우 안전하고 순응도가 높은 치료 방법이라 생각되었 다. 현재까지 추적기간이 짧아 치료의 급성독성과 순응도 만 평가할 수 있었지만 비교적 적극적 치료 방법임에도 불구 하고 안전한 치료방법이라 생각되었다. 또한 치료 반응률도 비교적 높아 생존율 향상이 장기추적조사에서 기대된다.

\section{결 론}

Paclitaxel과 cisplatin을 이용한 항암화학방사선 동시요법 의 치료 순응도는 비교적 높아 안전한 방법이라 생각되었
으며, 치료에 의한 반응 역시 높아 매우 희망적인 치료법이 라 생각되며 향후 더 많은 증례를 대상으로 장기 추적관찰 을 통한 치료성적의 평가가 필요할 것으로 판단된다.

\section{REFERENCES}

1. Bae JM, Won YJ, Jung KW, Suh KA, Ahn DH, Park JG. Annual report of the central cancer registry in Korea-1999: Based on registered data from 128 hospitals. Cancer Res Treat 2001;33(5):367-372.

2. LeChevalier T, Arriagada R, Quoix E, Ruffie P, Martin M, Tarayre M, Lacombe-Terrier MJ, Douillard JY, Laplanche A. Radiotherapy alone versus combined chemotherapy and raditherapy in nonresectable non-small cell lung cancer: First analysis of a randomized trial in 353 patients. J Natl Cancer Inst 1991;83:417-423.

3. Sause W, Kolesar P, Taylor S, Johnson D, Livingston R, Komaki R, Emami B, Curran Jr W, Byhardt R, Dar AR, Turrisi AT. Final results of phase III trial in regionally advanced unresectable non-small cell lung cancer. Chest 2000; 117:358-364.

4. Dillman RO, Herndon J, Seagren SL, Eaton WL Jr, Green MR. Improved survival in stage III non-small-cell lung cancer: sevenyear follow-up of cancer and leukemia group B (CALGB) 8433 trial. J Natl Cancer Inst 1996;88:1210-1215.

5. Le Chevalier T, Arriagada R, Quoix E, Ruffie P, Martin M, Tarayre M, Lacombe-Terrier MJ, Douillard JY, Laplanche A. Radiotherapy alone versus combined chemotherapy and radiotherapy in nonresectable non-small-cell lung cancer: First analysis of a randomized trial in 353 patients. J Natl Cancer Inst 1991;83:417-423.

6. Dillman RO, Seagren SL, Propert KJ, Guerra J, Eaton WL, Perry MC, Carey RW, Frei EF 3rd, Green MR. A randomized trial of induction chemotherapy plus high-dose radiation versus radiation alone in stage III non-small-cell lung cancer. N Engl J Med 1990;323:940-945.

7. Cerny T, Kaplan S, Pavlidis N, Schoffski P, Epelbaum R, van Meerbeek J, Wanders J, Franklin HR, Kaye S. Docetaxel (Taxotere) is active in non-small-cell lung cancer: a phase II trial of the EORTC early clinical trials group (ECTG). Br J Cancer 1994;70:384-387.

8. Tishler RB, Schiff PB, Geard CR, Hall EJ. Taxol: A novel radiation sensitizer. Int J Radiat Oncol Biol Phys 1992;22:613617.

9. Chang AY, Rubins J, Asbury R, Boros L, Hui LF. Weekly paclitaxel in advanced non-small cell lung cancer. Seminars in Oncology 2001;4S(14):10-13.

10. Lee S, Choi EK, Ahn SD, Yi BY, Kim JH, Kim SW, Suh CW, Lee JS, Kim WS, Kim DS, Kim WD-. 3D conformal radiotherapy and concurrent chemotherapy for stage III locally advanced inoperable non-small cell lung cancer. J Korean Cancer Assoc 2001 Suppl.

11. Sause WT, Scott C, Taylor S, Johnson D, Livingston R, Komaki R, Emami B, Curran WJ, Byhardt RW, Turrisi A. Radiation Therapy Oncology Group (RTOG 88-08) and Eastern Cooperative Oncology Group (ECOG) 4588: Preliminary results of a phase III trial in regionally advanced, unresectable, non-small cell lung cancer. J Natl Cancer Inst 1995;87:198205.

12. Perez CA, Pajak TF, Rubin P, Simpson JR, Mohiuddin M, Brady LW, Perez-Tamayo R, Rotman M. Long-term observations of the patterns of failure in patients with unresectable non-oat cell caricnoma of the lung treated with definitive 
radiotherapy. Cancer 1987;59:1874-1881.

13. Sause WT, Kolesar P, Taylor S, Johnson D, Livingston R, Komaki R, Emami B, Curran W Jr, Byhardt R, Dar AR, Turrisi A 3rd. Final results of phase III trial in regionally advanced unresectable non-small cell lung cancer: Radiation Therapy Oncology Group, Eastern Cooperative Oncology Group, and Southwest Oncology Group. Chest 2000;117:358364.

14. Jeremic B, Shibamoto Y, Acimovic L, Djuric L. Randomized trial of hyperfractionated radiation therapy with or without concurrent chemotherapy for stage III non-small-cell lung cancer. J Clin Oncol 1995;13:452-458.

15. Arriagada R, Le Chevalier T, Quoix E, Ruffie P, de Cremoux H, Douillard JY, Tarayre M, Pignon JP, Laplanche A. ASTRO (American Society for Therapeutic Radiology and Oncology) plenary: Effect of chemotherapy on locally advanced nonsmall cell lung carcinoma: a randomized study of 353 patients. Int J Radiat Oncol Biol Phys 1991;20:1183-1190.

16. Cox JD, Azarnia N, Byhardt RW, Shin KH, Emami B, Pajak TF. A randomized phase I/II trial of hyperfractionated radiation therapy with total doses of $60.0 \mathrm{~Gy}$ to $79.2 \mathrm{~Gy}$ : possible survival benefit with greater than or equal to $69.6 \mathrm{~Gy}$ in favorable patients with Radiation Therapy Oncology Group stage III non-small-cell lung carcinoma: report of Radiation Therapy Oncology Group 83-11. J Clin Oncol 1990;8:15431555.

17. Vijayakumar S, Myrianthopoulos LC, Rosenberg I, Halpern HJ, Low N, Chen GT. Optimization of radical radiotherapy with beam's eye view techniques for non-small cell lung cancer. Int J Radiat Oncol Biol Phys 1991;21:779-788.

18. Armstrong J, Burman C, Leibel S, Fontenla D, Kutcher G,
Fuks Z. Conformal three dimensional treatment planning may improve the therapeutic ratio of high dose radiation therapy for lung cancer. Int J Radiat Oncol Biol Phys 1993;26:685689.

19. Emami B, Purdy JA, Manolis J, Barest G, Cheng E, Coia L, Doppke K, Galvin J, LoSasso T, Matthews J. Three-dimensional treatment planning for lung cancer. Int J Radiat Oncol Biol Phys 1991;21:217-227.

20. Robertson JM, Ten Haken RK, Hazuka MB, Turrisi AT, Martel MK, Pu AT, Littles JF, Martinez FJ, Francis IR, Quint LE, Lichter AS. Dose escalation for non-small cell lung cancer using conformal radiation therapy. Int J Radiat Oncol Biol Phys 1997;37:1079-1085.

21. Hayman JA, Martel MK, Ten Haken RK, Normolle DP, Todd RF 3rd, Littles JF, Sullivan MA, Possert PW, Turrisi AT. Dose escalation in non-small-cell lung cancer using three-dimensional conformal radiation therapy: Update of a phase I trial. J Clin Oncol 2001;19:127-136.

22. Furuse K, Fukuoka M, Kawahara M, Nishikawa H, Takada Y, Kudoh S, Katagami N, Ariyoshi Y. Phase III study of concurrent versus sequential thoracic radiotherapy in combination with Mitomycin, Vindesine, and Cisplatin in unresectable stage III non-small-cell lung cancer. J Clin Oncol 1999;17:26922699.

23. Choy H, DeVore RF, Hande KR, Porter LL, Rosenblatt PA, Slovis B, Laporte K, Shyr Y, Johnson DH. Phase I trial of outpatient weekly docetaxel, carboplatin and concurrent thoracic radiation therapy for stage III unresectable non-small-cell lung cancer: a Vanderbilt cancer center affiliate network (VCCAN) trial. Lung Cancer 2001;34:441-449. 